\title{
Impact of Maternal Exposure to Wood Smoke Pollution on Fetal Lung Morphology in a Rat Model
}

\author{
Impacto de la Exposición Materna a la Contaminación por Humo \\ de Leña en la Morfología Pulmonar Fetal en un Modelo de Rata
}

Salinas, Paulo'; Veuthey, Carlos²; Bruna, Nicolás ${ }^{3}$; Bongiorno, Anthony ${ }^{4}$ \& Romero, Ingrid ${ }^{5,6}$

SALINAS, P.; VEUTHEY, C.; BRUNA, N.; BONGIORNO, A. \& ROMERO, I. Impact of maternal exposure to wood smoke pollution on fetal lung morphology in a rat model. Int. J. Morphol., 38(5):1250-1257, 2020.

SUMMARY: Residential heating with wood is an important source of ambient air pollution. Evidence links air pollution to serious health effects such as respiratory and cardiovascular mortality and morbidity. We hypothesized that prenatal exposure to wood smoke pollution causes morphological changes in the development of the rat lung, leading to altered lung structure and function during later life. We presumed that analysis of the fetal lung stereology provides novel insights into the underlying processes mediating particulate matter associated developmental changes and damage. The objective of the study was to investigate the effects of exposure during gestational period to wood smoke pollution on lung fetal morphology. To test this, pregnant rats were exposed during pregestational and gestational periods to wood smoke pollution. Complete lungs samples were obtained from 24 fetus from healthy female G3 rats subjected to cesarean at 19 days post-fecundation. The lungs were prepared for histological and stereological analysis. The volume fraction of terminal bronchioles $\mathrm{V}_{\mathrm{v}}\left[\mathrm{tb}, \mathrm{lung}\right.$ ] and volume fraction of parenchyma $\mathrm{V}_{\mathrm{v}}$ [par, lung], surface density of terminal bronchioles $S_{V}$ [tb, lung] as well as numerical density of bronchiolar exocrinocytes $N_{A}$ [ec,lung] were calculated by light microscopy. Statistical analysis detected significant differences between groups in volume density $\mathrm{V}_{\mathrm{v}}$ [tb, lung; \%] $(p=0.0012)$ and surface density $\mathrm{S}_{\mathrm{v}}$ [tb, lung; $\left.\mathrm{mm}^{2} / \mathrm{mm}^{3}\right](p<0.0001)$ of the terminal bronchioles. However, it did not show differences between groups in the stereological parameter volume density $\mathrm{V}_{\mathrm{v}}$ [par, lung; \%] ( $\left.p=0.0838\right)$ and numerical density of bronchiolar exocrinocytes $\mathrm{N}_{\mathrm{A}}$ [ec,lung; $\left.\mathrm{n}^{\circ} / \mathrm{mm}^{2}\right](p=0.0705)$. The analysis of the evidence obtained indicates that exposure to environmental pollution was affects lung maturation, and particularly the proportion and area of terminal bronchioles in the fetal lung. In conclusion, maternal exposure to wood smoke pollution during pregnancy was associated with a decrease in the lower conducting airways of lungs, which, according to urban pollution studies, could be related to early childhood lower respiratory illness. The public health implications of this study are that reducing or avoiding exposure to wood smoke is important before and during pregnancy.

KEY WORDS. Pollution; Smoke; Wood Smoke Pollution; Lung; Stereology; Rat; Temuco.

\section{INTRODUCTION}

Exposure to particulate matter (PM) is a major global health concern (GBD 2015 Risk Factors Collaborators, 2016; Di et al., 2017). According to the World Health Organization, approximately 8 million early deaths a year are attributed to the effects of air pollution (AP), including 500,000 deaths of young children due to pneumonia or nearly half of all deaths due to pneumonia in children under 5 years old. Also, more than $80 \%$ of people living in urban areas are exposed daily to levels that exceed the recommended limits compatible with health (WHO, 2018a,b; maximum exposure daily mean level of PM 2.5: $\left.25 \mathrm{mg} / \mathrm{m}^{3}\right)$. With increasing population densities, industrialization and urbanization, environmental AP is an increasing public health risk, particularly in developing and low-income regions (WHO, 2016). Airborne PM is the main pollutant used to assess its quality and related public health risks (Burnett et al., 2014; WHO, 2016). Fine particle AP and hospital admission for cardiovascular and

\footnotetext{
${ }^{1}$ Institute of Biology, Faculty of Sciences, Pontificia Universidad Católica de Valparaíso, Valparaíso, Chile.

${ }^{2}$ Center for Research in Dental Sciences, Faculty of Dentistry, Universidad de La Frontera, Temuco, Chile.

${ }^{3}$ School of Medical Technology, Faculty of Sciences, Pontificia Universidad Católica de Valparaíso, Valparaíso, Chile.

${ }^{4}$ Department of Biology, Middlebury College, Vermont, United States of America..

${ }^{5}$ Doctorate Program in Morphological Sciences, Universidad de La Frontera, Temuco, Chile

${ }^{6}$ Faculty of Health Sciences, Department of Diagnostic Processes and Evaluation, School of Nutrition, Universidad Católica de Temuco, Temuco, Chile.
} 
respiratory diseases have been associated (Dominici et al., 2006). The composition of the PM is variable and depends on the type of emission source, among others. In the respiratory system, its deposition depends mainly on the aerodynamic diameter of the inhaled particles. Deposits of PM throughout the respiratory system depend on the aerodynamic diameter of the particles (Kelly \& Fussell, 2012). The fraction of particles with an aerodynamic diameter of less than $2.5 \mathrm{~mm}$ (PM 2.5) is considered small enough to reach alveolar spaces, with ultrafine particles $(<0.1 \mathrm{~mm})$ that can cross the air/blood barrier.

Exposure to AP during the gestational stage has significant effects on the lungs during development, and altered prenatal lung development impairs lung function and lung growth and increases risk for respiratory disease in childhood and adulthood (Berry et al., 2016). This, consequently, has led to an increase in the prevalence of chronic respiratory diseases, such as asthma (Håland et al., 2006). Most of the studies describe epidemiological antecedents or effects on the lungs associated with AP whose main source of emission toxic substances are diesel engine or tobacco, ignoring the effects of heavy wood smoke pollution produced by residential heating. Currently in southern Chile, wood and other biomass fuels are frequently used for residential heating. Some authors have associated its use to conditions of poverty, citizens without access to modern fuels, who must resort to the collection of biomass for their domestic cooking and heating needs. In fact, these activities that started a third of million years ago still occur daily in more than $40 \%$ of human homes. In recent decades, due in part to disciplines such as epidemiology and toxicology, and changing expectations about health protection, PM generated by firewood combustion have been considered as important health risk factors in almost all populations. Wood smoke pollution (humidity above $25 \%$ ) produced by residential heating is a serious problem affecting South-Central Chile (below $35^{\circ} \mathrm{S}$; Sanhueza et al., 2006; Cereceda-Balic et al., 2012; Schueftan \& González, 2013; Schiappacasse et al., 2013; Villalobos et al., 2017). This is caused by the excessive and widespread use of wood - one of the cheapest fuels available - for heating in inefficient stoves and in homes with poor thermal insulation.

In Chile, the effects of AP on health have been studied mainly in Santiago and Temuco, due to the existence of monitoring stations and databases (Sanhueza et al., 2009). Temuco (38 $\left.44^{\prime} 24^{\prime \prime} \mathrm{S} 72^{\circ} 35^{\prime} 24^{\prime \prime} \mathrm{W}\right)$ is located in the south central of Chile and has been consoled in recent years as one of the most polluted cities in Latin America (WHO, 2018a; IQ Air, 2020). Residential heating is an essential energy service required by many people worldwide. Firewood burnt in stoves with inefficient technology generates a large amount of PM emissions in the ambient air. Temuco was declared a saturated zone, presenting episodes of high PM concentration, which have been exceeded systematically values defined by Chilean national air quality standards (NAQS), and World Health Organization (WHO, 2018a) standards. In Chile, AP in some cities is stationary, and generally originates from the domestic heating habits of its citizens (Reyes et al., 2019; Boso et al., 2020). According to the latest PM10 emissions inventory published in the city of Temuco, wood smoke pollution is the main source of AP, accounting for $93 \%$ of emissions, which is considered (Díaz-Robles et al.; Cereceda-Balic et al.; Villalobos et al.) as a city with a "single emission source" (monosource). Epidemiological studies carried out in Temuco have reported a significant association between daily medical consultations for respiratory diseases and daily ultrafine particles (Díaz-Robles et al.).

Based on previous findings indicating that pre- and gestational exposure of mice to urban-level AP synergistically affect lung development (Mauad et al., 2008), we hypothesized that prenatal exposure to wood smoke pollution causes morphological changes in the development of the rat lung that are already determined in utero, leading to altered lung structure and function during later life. We presumed that fetal lung stereology provides novel insights into the underlying processes mediating PMassociated developmental changes and damage. The objective of the study was to investigate the effects of exposure during gestational period to environmental pollution by wood smoke on lung fetal morphology.

\section{MATERIAL AND METHOD}

All animal experiments should be carried out in accordance with the Law 20,380 (Ministry of Agriculture, 2009) in accordance with national and institutional guidelines for animal welfare and the National Institutes of Health Guide for the Care and Use of Laboratory Animals (National Research Council (US) Committee for the Update of the Guide for the Care and Use of Laboratory Animals, 2011). The animals in this study were treated humanely, with proper consideration given to alleviate distress and discomfort. The Sprague-Dawley rats $(n=48)$, second generation (G2) were used. The rats were fed a balanced diet and water ad libitum. They permanently received veterinary assistance. The euthanasia procedure (unrelated to this research) was carried out in accordance with AVMA Guidelines on Euthanasia (Nolen, 2011). In 
addition, to reduce the "father's bias", only males that were gestated and reared in an indoor environment were used.

Site of exposure, exposure conditions and air analysis. The rats were exposed in Temuco (southern Chile) at the Center for Morphological and Surgical Studies (CEMyQ; Universidad de La Frontera; $38^{\circ} 44^{\prime} 59.4^{\prime \prime S} 72^{\circ} 37^{\prime} 07.8^{\prime \prime}$ $\mathrm{W})$ in one area where there were firewood combustion sources for residential heating 24 hours a day. We evaluated the association between AP exposure produced by wood smoke pollution on the macroscopic and microscopic morphology of the lung in rats using a timestratified crossover case design. The study was carried out in the southern winter season, from July 15 to October 30,2018 . The exposure was simulated using two different environments side by side according to what was used by Veras et al. (2008). The outdoor environment consisted of an outdoor chamber (outdoor chamber; $5.0 \mathrm{~m} \mathrm{x} 5.0 \mathrm{~m} \mathrm{x}$ $2.1 \mathrm{~m}$ high) receiving ambient air at a flow rate of $22 \mathrm{~m}^{3}$ $\mathrm{m}^{-1}$. In the outer chamber, air flow entered and distributed within it before exiting through a window. Meanwhile, the windows of the indoor chamber were kept closed 20 hours a day, reducing the passage of ventilation air from the outside to the inside. The $24 \mathrm{~h}$ concentrations of PM2.5 and PM10 inside both chambers were measured using an ambient continuous monitor (HT9600, Guangdong, China). The concentration of the outside environment was determined by Beta Attenuation Monitors (Raja et al., 2017) using MetOne 1020 BAMs (The Met One Instruments, Inc. model BAM-1020). Concentrations of $\mathrm{CO}$ (8-h mean) was determined by a non-dispersive infrared method. All samples were collected by "Algoritmos y Mediciones Ambientales SpA" from the "Las Encinas Monitoring Station" of the National Air Quality Information System, which is located just 200 meters from the exposure chamber site and was provided online by the National Air Quality Information System (https://sinca.mma.gob.cl) for use in this research.

Experimental Design. We exposed two generations of rats to AP by wood smoke pollution and used the second generation (G2) to investigate the effects caused by prenatal exposure from previous generations. We used four groups of primiparous G2 rats, continuously exposed from birth to caesarean day, 19 days post fecundation (dpf). G2 rats were continuously exposed to an indoor (In) or outdoor (Out) environment from pregestational period (birth to the first day of pregnancy), each group was subsequently subdivided into two exposure groups (outdoor or indoor, $\mathrm{n}=12$ ) during the gestation period. $\mathrm{G} 2$ rats were obtained using the following protocol: 20-day-old rats (G0: 10 males and 10 females) were kept in indoor (In: 5 pairs) and outdoor (Out: 5 couples) chambers. The rats mated in their respective chambers at 60 days of age. The G1 were obtained from full-term gestations that developed in both chambers and subsequently remained in them. Upon reaching reproductive maturity, mating of 10 pairs of G1 rats ( 5 couples per chamber) was performed. The $\mathrm{G} 2$ rats were obtained from the mating period of 10 pairs of G1 rat kept (In: 5 pairs; Out: 5 pairs) kept in cages until they reached the reproductive age (60 days approx.). To determine the stage of the estrous cycle, daily vaginal cytology was performed. The presence of a vaginal plug and sperm in the vagina was used to assess whether mating occurred and determine the first day of gestation. After mating, the females were divided into four study groups, defined as: Indoor/Indoor (In/In; female G2 rats that were raised and also presented a full-term pregnancy in an indoor exposure chamber), Indoor/Outdoor (In/Out; female G2 rats that were raised in outdoor chamber and presented a full-term pregnancy in an indoor exposure chamber) and Outdoor/ Indoor (Out/In; female $\mathrm{G} 2$ rats that were raised in outdoor chamber and presented a full-term pregnancy in an indoor exposure chamber) and Outdoor/Outdoor (Out/Out; female $\mathrm{G} 2$ rats that were raised and also presented a fullterm pregnancy in an indoor exposure chamber). All the rats $\mathrm{G} 2$ included in this study demonstrated at least one estrus. We used an environmental pollution exposure model based on Veras et al.

Fixation, sampling and processing. Complete lungs samples were obtained from 24 fetuses of healthy female G3 rats subjected to cesarean section $19 \mathrm{dpf}$ from each study group. No gross abnormalities were present. Six lungs per litter were randomly selected. The lungs were fixed by airway instillation of a mixture of $1.5 \%$ formaldehyde (prepared from freshly depolymerized paraformaldehyde) and $1.5 \%$ glutaraldehyde in $0.1 \mathrm{M}$ sodium cacodylate buffer ( $\mathrm{pH} 7.35$; buffer osmolarity 300 $\mathrm{mOsm} / \mathrm{l})$ at a pressure of $25 \mathrm{~cm}$ water. After fixation for at least 24 hours, the whole lung was cut into horizontal slices of $2 \mathrm{~cm}$ thickness, starting with a random apical position between 0 and $2 \mathrm{~cm}$. Each slice was photographed for lung volume determination by the Cavalieri principle. For systematic, uniformly random sampling of tissue blocks, the organ slices were then placed in a processing tray with the apical section face up. A transparent point grid with $8 \times 8$ holes (distance between holes $4 \mathrm{~cm}$ ) was superimposed over the slices. Needles were inserted in the holes to define the lower left corner of the tissue blocks to be excised. For light microscopical analysis, a block of a size of $1 \times 1 \times 2 \mathrm{~cm}^{3}$ was excised. Sections of 1 to $2 \mathrm{~mm}$ thickness were cut from the upper, front and right face of the cube in a systematic random fashion to have, for all practical purposes, all three dimensions represented. The samples were osmicated, dehydrated through a graded se- 
ries of ethanol and finally embedded in Paraplast (Paraplast Plus embedding medium; melting point: $54{ }^{\circ} \mathrm{C}$; SigmaAldrich Chemical Co., St Louis, MO, USA). Serial sections were made ( $5 \mu \mathrm{m}$ thick) with a motorized rotary microtome Leica RM2255 (Leica Microsystems, Switzerland). Then, the sections were rehydrated, immersed in xylol (10 min), exposed to descending concentrations of ethanol $(100 \%, 96 \%, 80 \%$ and $70 \%$, all $15 \mathrm{~s}$ ) and finally distilled water. Cross-histological section of lung were stained with hematoxylin and eosin and scanned using a Motic Easy Scan ${ }^{\circledR}$ Pro Digital slide scanner (Motic Instrument Inc, Canada) to produce fully digital panoramic views.

Lung stereology. In order to view each lung a cross section in its entirety, selected SUR slides were photographed using a $4 \mathrm{x}$ objective lens was for to estimate $\mathrm{V}_{\mathrm{v}}$ of the lung parenchymal fraction, 20X to estimate $\mathrm{V}_{\mathrm{v}}$ and $\mathrm{S}_{\mathrm{V}}$ of the terminal bronchiole, and $100 \mathrm{X}$ to quantify the $\mathrm{N}_{\mathrm{A}}$ of bronchial exocrinocytes. For stereology, sampling and acquisition of unbiased stereological estimators were performed according Mühlfeld \& Ochs (2013. Serial histological sections ( $300 \mu \mathrm{m}$ intervals) $5 \mu \mathrm{m}$ thick were analyzed; each stereological data was estimated by examining 5 microscopic fields per sample. For unbiased stereology, in the lung, the volume fraction of terminal bronchioles $\mathrm{V}_{\mathrm{v}}$ [tb, lung] and volume fraction of parenchyma $\mathrm{V}_{\mathrm{v}}$ [par, lung] (estimated by point counting; $\%$ ), surface density of terminal bronchioles $\mathrm{S}_{\mathrm{v}}$ [tb, lung] (estimated by intersection counting; $\mathrm{mm}^{2} / \mathrm{mm}^{3}$ ) as well as numerical density of bronchiolar exocrinocytes $\mathrm{N}_{\mathrm{A}}$ [ec, lung] (estimated by profile counting) were calculated by light microscopy at 100x. All stereology evaluations considered tissue deformation (Dorph-Petersen et al., 2001). Two trained observers performed all measurements, each using their own microscope and computer software, unaware to the identity of the groups to avoid bias. The $\mathrm{M}$ 36 test system provided by the STEPanizer Stereological Tool software (Tschanz et al., 2011) was used, utilizing 36 test points; the test line measures $16 \mathrm{~d}$ and the test area measures $36.36 \mathrm{~d}^{2}$. The overlapping program analyzed images from labyrinth. All measurements were performed by two trained observers, each using their own microscope and computer software, blinded to the identity of the groups.

Statistical analyses. Data were expressed as mean \pm standard deviation (SD) and interquartile range. The data distributions of continuous variables were tested for normality by means of the D'Agostino Pearson Test. Stereological data were analyzed by one-way ANOVA among the three groups and by Tukey's post-test of multiple comparisons. Statistical significance for all of hypotheses tests was set at $p<0.05$ and $95 \%$ Confidence Interval. The data analysis was performed using GraphPad Prism 8.0 software for Mac OS X (GraphPad Software, San Diego CA).

\section{RESULTS}

Normality test showed the data was normally distributed. Therefore, a parametric test was used for statistical analysis. The ANOVA test and Tukey's post hoc tests of multiple comparisons were used to identify significant differences on stereological variables in lung.

Exposure assessment. During experimental period, the daily mean outdoor levels of PM 2.5, PM 10 and CO in Temuco-Padre Las Casas were $47.74 \mathrm{mg} / \mathrm{m}^{3}( \pm 35.9$; $\mathrm{CV}=86.69 \%), 56.4 \mathrm{mg} / \mathrm{m}^{3}( \pm 35.5 ; \mathrm{CV}=70.95 \%)$ and 0.65 ppm $( \pm 0.44, C V=85.10 \%)$, respectively. During gestational period, the daily mean indoor levels of PM 2.5 (inside two chambers) were $59.54 \mathrm{mg} / \mathrm{m}^{3}$ for outside group (Out/Out group; $\pm 29.5 ; C V=49.19 \%$; $\min -\max : 7-109$ ) and $42.36 \mathrm{mg} / \mathrm{m}^{3}$ for inside group (In/In group; \pm 22.1 ; $\mathrm{CV}=33.22 \%$; $\min -\max : 6-51)$, demonstrating a nearly 1.5 -fold difference ( $p$-value $<0.0001$ ). Maternal exposure was estimated by multiplying the total volume of inhaled air during gestation $(1120 \mathrm{~L}=19$ days $\times 1440 \mathrm{~min} \times$ minute volume of inhaled air taken to be $0.041 \mathrm{~L} / \mathrm{min}$ ) by the mean $24 \mathrm{~h}$ concentration of PM 2.5. The estimated amount inhaled by Out/Out females was $66789.591 \mathrm{mg} / \mathrm{m}^{3}$ during the whole gestation period and $3515.2 \mathrm{mg} / \mathrm{m}^{3}$ daily and for $\mathrm{In} / \mathrm{In}$ females was $47443.21 \mathrm{mg} / \mathrm{m}^{3}$ and $2497.01 \mathrm{mg} /$ $\mathrm{m}^{3}$, respectively.

Histological and stereological analysis. Histological analysis revealed that the fetal lungs of the Out/Out group were in the canicular stage. The In/In, In/Out and Out/In groups were in a transition to the saccular stage (Fig. 1). Well-defined terminal bronchioles were identified in all groups, however, in those groups where a greater degree of lung maturity was observed, a greater presence of bronchial exocrinocytes was visualized. The Out/Out group presented a disorganized cellular arrangement in the lung parenchyma and presented a lower number of blood vessels compared to In/In. Statistical analysis detected significant differences between groups in volume density VV [tb, lung; $\%](p=0.0012)$ and surface density $\mathrm{S}_{\mathrm{v}}\left[\mathrm{tb}\right.$, lung; $\left.\mathrm{mm}^{2} / \mathrm{mm}^{3}\right]$ $(p<0.0001)$ of the terminal bronchioles. However, it did not show differences between groups in the stereological parameter volume density $\mathrm{V}_{\mathrm{v}}$ [par, lung; $\left.\%\right](p=0.0838)$ and numerical density of bronchiolar exocrinocytes $\mathrm{N}_{\mathrm{A}}$ [ec,lung; $\left.\mathrm{n}^{\mathrm{O}} / \mathrm{mm}^{2}\right]$ ( $\left.p=0.0705\right)$ (Fig. 2; Table I). 

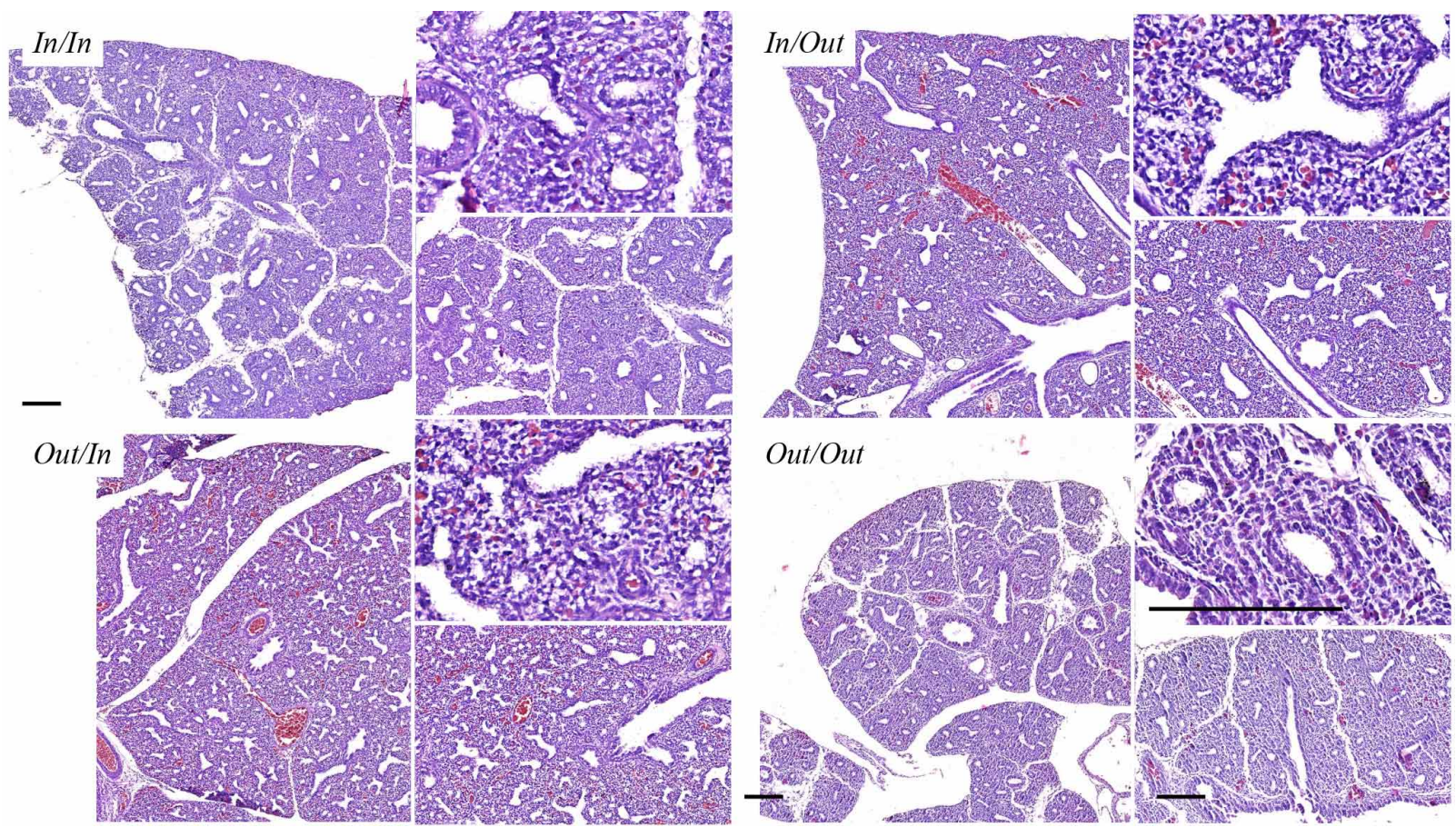

Fig. 1. Light micrograph showing the typical fine lace appearance of an expanded fetal lung. The parenchyma has not yet small alveoli, however present some larger airways ducts (mostly terminal bronchioles) and blood vessels (H-E; Bar: 200 micras).

A

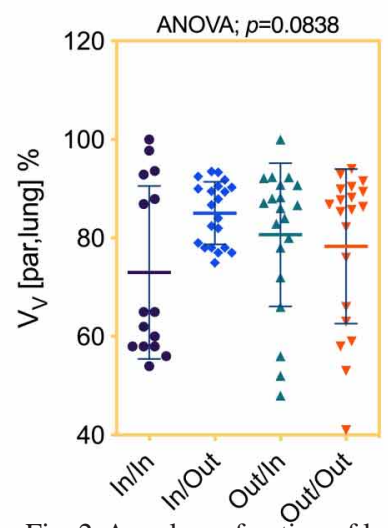

B

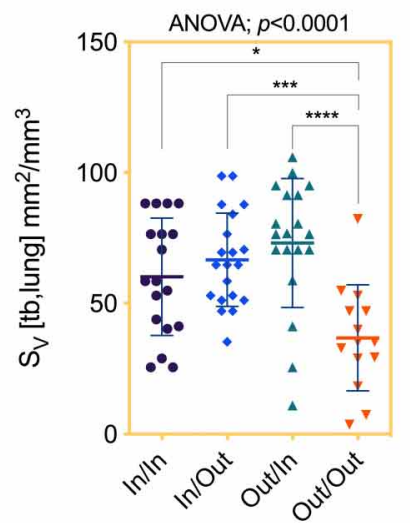

C

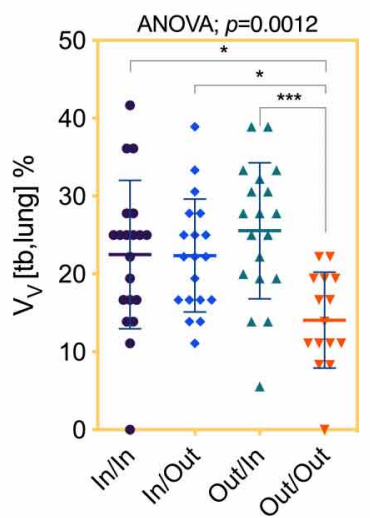

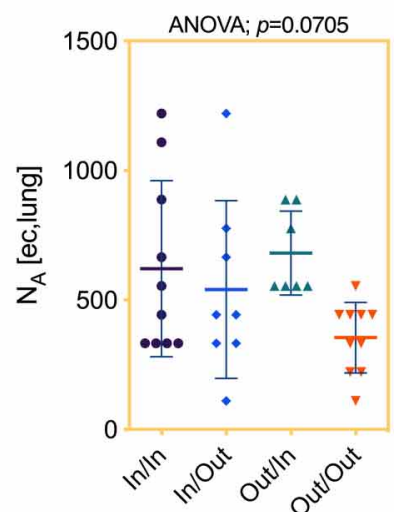

Fig. 2. A, volume fraction of lung parenchyma $\mathrm{V}_{\mathrm{V}}$ [par, lung] (estimated by point counting; \%). B, surface density of terminal bronchioles $\mathrm{S}_{\mathrm{V}}$ [tb, lung] (estimated by intersection counting; $\mathrm{mm}^{2} / \mathrm{mm}^{3}$ ). C, volume fraction of terminal bronchioles $\mathrm{V}_{\mathrm{v}}$ [tb, lung]. D, numerical density of bronchiolar exocrinocytes $\mathrm{N}_{\mathrm{A}}$ [ec,lung] (estimated by profile counting) were calculated by light microscopy at 40 and $100 \mathrm{X}$

Table I. The effects of the exposure period (pregestational and gestational) on pulmonary parenchyma, terminal bronchiole and bronchiolar exocrinocytes. Data are expressed as mean $\pm \mathrm{SD}(\mathrm{CV})$

\begin{tabular}{cccccc}
\hline & In/In & In/Out & Out/In & Out/Out & $p$-value \\
\hline $\mathrm{V}_{\mathrm{V}}$ [par, lung] & $73 \pm 17.56(24.0)$ & $85.04 \pm 6.34$ & $80.66 \pm 14.53$ & $78.32 \pm 15.70$ & 0.0838 \\
& & $(7.46)$ & $(18.01)$ & $(20.05)$ & \\
$\mathrm{S}_{\mathrm{V}}$ [tb, lung] & $60.18 \pm 22.40$ & $66.68 \pm 17.87$ & $73.08 \pm 24.66$ & $36.82 \pm 20.24$ & $\mathrm{P}<0.0001$ \\
& $(37.22)$ & $(26.80)$ & $(37.75)$ & $(54.98)$ & \\
$\mathrm{V}_{\mathrm{V}}$ [tb, lung] & $22.50 \pm 9.53$ & $22.37 \pm 7.26$ & $25.55 \pm 8.74$ & $14.07 \pm 6.16$ & 0.0012 \\
& $(42.37)$ & $(32.45)$ & $(34.20)$ & $(43.81)$ & \\
$\mathrm{N}_{\mathrm{A}}$ [ec,lung] & $621.0 \pm 339.6$ & $540.6 \pm 342.7$ & $681.1 \pm 162.3$ & $354.8 \pm 136.3$ & 0.0705 \\
& $(54.68)$ & $(63.40)$ & $(23.83)$ & $(38.41)$ & \\
\hline
\end{tabular}

Volume fraction of terminal bronchioles: $\mathrm{V}_{\mathrm{V}}\left[\mathrm{tb}\right.$, lung; \%]. Volume fraction of parenchyma: $\mathrm{V}_{\mathrm{v}}$ [par, lung; \%]. Surface density of terminal bronchioles: $\mathrm{S}_{\mathrm{V}}$ [tb, lung; $\mathrm{mm}^{2} / \mathrm{mm}^{3}$ ]. Numerical density of bronchiolar exocrinocytes: $\mathrm{N}_{\mathrm{A}}$ [ec,lung; $\mathrm{n} / \mathrm{mm}^{2}$ ] 


\section{DISCUSSION}

In the present study we have hypothesized that prenatal exposure to wood smoke pollution causes morphological changes in the development of the rat lung that are already perceptive in utero, leading to altered lung structure and function during later life. We approached our research question using a stereological methodology as it provides novel quantitative data into the underlying processes mediating PM-associated developmental changes or damage. To our knowledge, it is the first morphologic study to suggest that prenatal exposure - during gestational stage - to AP caused by wood smoke pollution from residential heating may have a negative impact on the development of the fetal lung in a murine model. In this study, we aimed to investigate quantitative effects for lung development deficits due to in utero wood smoke pollution, by using an animal model of maternal exposure. We found statistically significant evidence that concentrations of $59.54 \mathrm{mg} / \mathrm{m}^{3}$ of long-term exposure to PM2.5 caused by wood smoke pollution are associated with an effect on the maturation of lung fetal tissue and also on the air conduction system, especially the size of the terminal bronchioles. This analysis provides a timely characterization of the relationship between exposure to AP, in an area historically declared a saturated area, and events in the lung that could trigger longterm chronic diseases with a high frequency of presentation in the adult population from southern Chile. The scientific novelty of this research proposal is the use of rats in real environmental conditions, and use of exposure chambers to wood smoke pollution. Prior studies have shown that AP impacts heart health and affect breathing and lung function, but less is known about whether AP affects lung development during prenatal exposure. Most of the studies cited in this research proposal describe the health effects or respiratory system produced by AP, however, the majority have been conducted in environments whose main source of PM emission is fuel combustion by motor vehicles and industries ignoring the effects produced by the wood smoke pollution.

From our results, we can infer that there is a morphological effect on the air conductive system of the fetal lung when the mother was exposed prior to and during pregnancy (Out/Out). Unlike previous studies, we did not observe an effect from wood smoke pollution limited only to the pregestational or gestational stage, it is difficult to be certain of a critical time window. The analysis of the evidence obtained, indicates that exposure to environmental pollution affects lung maturation, and particularly the proportion and area of terminal bronchioles in the fetal lung. Our findings that prenatal exposure to $\mathrm{AP}$ is associated with reduced terminal bronchioles, these suggest a probable reduction in the ratio peak tidal expiratory flow:expiratory time and consequently respiratory compliance, which is consistent with the prenatal literature described in tobacco (McEvoy \& Spindel, 2017) and animal models of prenatal particle exposure (Tang et al., 2017). Alterations in expiratory flow and compliance may reflect changes in growth development and airway caliber. Also, our data suggests that fetuses born to mothers exposed to wood smoke pollution during the pregestational and gestational stages are at increased risk for lung failure once born. This lung failure could alter lung development and may begin to program future respiratory diseases from the uterus. Lee et al. (2019) and McEvoy et al. (2014) describe that lung function in childhood is inversely related to maximum "forced expiratory volume", a determinant of chronic respiratory disease in adulthood, such as chronic obstructive pulmonary disease (Håland et al.; Lange et al., 2015) and mortality (Vasquez et al., 2017). Therefore, changes in lung function in the first years of life could establish future respiratory health conditions. Our data coincide with those described in the literature for other types of PM2.5 pollutants, which suggest that prenatal exposure to AP can "prime or fetal programming " a developing lung in utero, to a postnatal injury secondary to one continuous exposure (Mauad et al.). Prenatal environmental conditions are important determinants of disease in adulthood (fetal programming), supported by experimental epidemiological and animal data. There is evidence that affirms that maternal exposure to ambient AP and environmental, particularly tobacco smoke during pregnancy, reduces lung function in offspring, which in turn can determine low lung function in adulthood associated with risk of chronic diseases or increased risk of COPD (Jedrychowski et al., 2010; Berry et al.; McEvoy \& Spindel).

From the results of this study we can hypothesize that chronic and long-term exposure to MP2.5 levels that exceed those recommended by the WHO would increase the lung's vulnerability to negative respiratory results or the presence of a cumulative effect, this would explain the high mortality rate that the population of Temuco during the coronavirus COVID-19 pandemic. A hypothesis regarding the high mortality rate that the population of Temuco presented during the coronavirus COVID-19 pandemic suggests an increase in vulnerability to experiencing serious results, or the presence of a cumulative effect on the respiratory system from daily and chronic exposure to MP2.5 levels that exceed those recommended by the WHO. The results of this study are a small contribution that supports the "fetal origins hypothesis" that an adverse environmental environment could affect not only fetal growth (reported previously), but could influence long-term lung function during adult life. Deben discutirse algunas limitaciones de este estudio. Some limitations of this study should be 
discussed. First, and even though these were minimized, it is possible that results may have been subject to father bias, given the aspects while obtaining the rat litters. Second, in view of the nature of this study, we infer the effects of gestational exposure to wood smoke pollution on adult lungs, in general, due to the lack of experimental studies, based on studies of environmental pollution whose source is diesel combustion and third, the relatively small sample size and lack of dietary data.

In conclusion, maternal exposure to wood smoke pollution during pregnancy was associated with a decrease in the lower conducting airways of lungs, which, according to urban pollution studies, could be related to early childhood lower respiratory illness. The public health implications of this study are that reducing or avoiding exposure to wood smoke pollution is important before and during pregnancy. On the other hand, wood smoke pollution has a great impact on public health that, in theory, it is possible to prevent.

FUNDING. DI-PUCV 039.378/2019. Dirección de Investigación. Pontificia Universidad Católica de Valparaíso.

SALINAS, P.; VEUTHEY, C.; BRUNA, N.; BONGIORNO, A. \& ROMERO, I. Impacto de la exposición materna a la contaminación por humo de leña en la morfología pulmonar fetal en un modelo de rata. Int. J. Morphol., 38(5):1250-1257, 2020.

RESUMEN: La calefacción residencial con leña es una fuente importante de contaminación ambiental. La evidencia vincula la contaminación del aire con graves efectos sobre la salud, como la mortalidad y la morbilidad respiratoria y cardiovascular. Hipotetizamos que la exposición prenatal a la contaminación por humo de leña causa cambios en el desarrollo del pulmón de rata, lo que conduce a una morfo-función pulmonar alteradas durante la vida posterior, creemos que el análisis de la estereología pulmonar fetal proporcionará nuevos conocimientos sobre los procesos subyacentes que median esos cambios. El objetivo del estudio fue investigar los efectos de la exposición prenatal a la contaminación ambiental por humo de leña sobre la morfología pulmonar fetal. Ratas preñadas fueron expuestas durante los períodos pregestacional y gestacional a la contaminación por humo de leña. En fetos de 19 días post-fecundación fue obtenido el pulmón para análisis histológico y estereológico. Fue determinado la fracción de volumen de bronquiolos terminales $\mathrm{V}_{\mathrm{v}}$ [tb, pulmón], fracción de volumen del parénquima $\mathrm{V}_{\mathrm{v}}$ [par, pulmón], densidad superficial de los bronquiolos terminales $\mathrm{S}_{\mathrm{v}}$ [tb, pulmón] así como la densidad numérica de exocrinocitos $\mathrm{N}_{\mathrm{A}}$ [ec, pulmón]. El análisis estadístico detectó diferencias significativas entre grupos en la densidad de volumen $\mathrm{V}_{\mathrm{v}}$ [tb, pulmón; \%] $(p=0,0012)$ y densidad superficial $\mathrm{S}_{\mathrm{v}}\left[\mathrm{tb}\right.$, pulmón; $\left.\mathrm{mm}^{2} / \mathrm{mm}^{3}\right]$ $(p<0,0001)$ de los bronquiolos terminales. Sin embargo, no demostró diferencias entre grupos en la densidad de volumen $\mathrm{V}_{\mathrm{v}}$ [par, pulmón; \%] $(\mathrm{p}=0,0838)$ y numérica de exocrinocitos bronquiolares $\mathrm{N}_{\mathrm{A}}$ [ec, pulmón; $\mathrm{n}^{\circ} / \mathrm{mm}^{2}$ ] $(p=0,0705)$. El análisis de la evidencia obtenida indica que la exposición a la contaminación ambiental afectó la maduración pulmonar, y particularmente la proporción y área de bronquiolos terminales en el pulmón fetal. En conclusión, la exposición materna a la contaminación por humo de leña durante la gestación se asoció a una disminución de las vías respiratorias conductoras de aire en pulmón, lo que, según estudios de contaminación urbana, podría estar relacionado con enfermedades de las vías respiratorias inferiores en la primera infancia. Las implicaciones para la salud pública de este estudio son que reducir o evitar la exposición al humo de leña es importante previo y durante la gestación. Por otro lado, la contaminación por humo de leña tiene un gran impacto en la salud pública que, en teoría, es posible prevenir.

PALABRAS ClAVE: Contaminación; Humo; Humo de Madera; Pulmón; Estereología; Rata; Temuco.

\section{REFERENCES}

Berry, C. E.; Billheimer, D.; Jenkins, I. C.; Lu, Z. J.; Stern, D. A.; Gerald, L. B.; Carr, T. F.; Guerra, S.; Morgan, W. J.; Wright, A. L.; et al. A distinct low lung function trajectory from childhood to the fourth decade of life. Am. J. Respir. Crit. Care Med., 194(5):607-12, 2016.

Boso, Á.; Álvarez, B.; Oltra, C.; Garrido, J.; Muñoz, C. \& Hofflinger, Á. Out of sight, out of mind: participatory sensing for monitoring indoor air quality. Environ. Monit. Assess., 192(2):104, 2020.

Burnett, R. T.; Pope, C. A. 3rd; Ezzati, M.; Olives, C.; Lim, S. S.; Mehta, S.; Shin, H.H.; Singh, G.; Hubbell, B.; Brauer, M.; et al. An integrated risk function for estimating the global burden of disease attributable to ambient fine particulate matter exposure. Environ. Health Perspect., 122(4):397-403, 2014.

Cereceda-Balic, F.; Fadic, X.; Llanos, A. L.; Dominguez, A. M.; Guevara, J. L.; Vidal, V.; Díaz-Robles, L. A.; Schiappacasse, L. N. \& Etcharren, P. Obtaining polycyclic aromatic hydrocarbon concentration ratios and molecular markers for residential wood combustion: Temuco, a case study. J. Air Waste Manag. Assoc., 62(1):44-51, 2012.

Di, Q.; Wang, Y.; Zanobetti, A.; Wang, Y.; Koutrakis, P.; Choirat, C.; Dominici, F \& Schwartz, J. D. Air pollution and mortality in the Medicare population. N. Engl. J. Med., 376(26):2513-22, 2017.

Díaz-Robles, L. A.; Ortega, J. C.; Fu, J. S.; Reed, G. D.; Chow, J. C.; Watson, J. G. \& Moncada-Herrera, J. A. A hybrid ARIMA and artificial neural networks model to forecast particulate matter in urban areas: The case of Temuco, Chile. Atmos. Environ., 42(35):8331-40, 2008.

Dominici, F.; Peng, R. D.; Bell, M. L.; Pham, L.; McDermott, A.; Zeger, S. L.; \& Samet, J. M. Fine particulate air pollution and hospital admission for cardiovascular and respiratory diseases. JAMA, 295(10):1127-34, 2006.

Dorph-Petersen, K. A.; Nyengaard, J. R. \& Gundersen, H. J. Tissue shrinkage and unbiased stereological estimation of particle number and size. J. Microsc., 204(Pt. 3):232-46, 2001.

GBD 2015 Risk Factors Collaborators. Global, regional, and national comparative risk assessment of 79 behavioural, environmental and occupational, and metabolic risks or clusters of risks, 1990-2015: a systematic analysis for the Global Burden of Disease Study 2015. Lancet, 388(10053):1659-724, 2016.

Håland, G.; Carlsen, K. C.; Sandvik, L.; Devulapalli, C. S.; Munthe-Kaas, M. C.; Pettersen, M.; Carlsen, K. H. \& ORAACLE. Reduced lung function at birth and the risk of asthma at 10 years of age. N. Engl. J. Med., 355(16):1682-9, 2006. 
IQ Air. 2019 World Air Quality Report. Region \& City PM2.5 Ranking. IQ Air, 2020. Available from: https://www.airvisual.com/world-mostpolluted-cities/world-air-quality-report-2019-en.pdf

Jedrychowski, W. A.; Perera, F. P.; Maugeri, U.; Mroz E.; KlimaszewskaRembiasz, M.; Flak, E.; Edwards, S. \& Spengler, J. D. Effect of prenatal exposure to fine particulate matter on ventilatory lung function of preschool children of non-smoking mothers. Paediatr. Perinat. Epidemiol., 24(5):492-501, 2010.

Kelly, F. J. \& Fussell, J. C. Size, source and chemical composition as determinants of toxicity attributable to ambient particulate matter. Atmos. Environ., 60:504-26, 2012.

Lange, P.; Celli, B.; Agustí, A.; Boje Jensen, G.; Divo, M.; Faner, R.; Guerra, S.; Marott, J. L.; Martinez, F. D.; Martinez-Camblor, P.; et al. Lungfunction trajectories leading to chronic obstructive pulmonary disease. N. Engl. J. Med., 373(2):111-22, 2015.

Lee, A. G.; Kaali, S.; Quinn, A. K.; Delimini, R.; Burkart, K.; OpokuMensah, J.; Wylie, B. J.; Yawson, A. K.; Kinney, P. L.; Ae-Ngibise, K. A.; et al. Prenatal household air pollution is associated with impaired infant lung function with sex-specific effects. evidence from GRAPHS, a cluster randomized cookstove intervention trial. Am. J. Respir. Crit. Care Med., 199(6):738-46, 2019.

Mauad, T.; Rivero, D. H.; de Oliveira, R. C.; Lichtenfels, A. J.; Guimarães, E. T.; de Andre, P. A.; Kasahara, D. I.; Bueno, H. M. \& Saldiva, P. H. Chronic exposure to ambient levels of urban particles affects mouse lung development. Am. J. Respir. Crit. Care Med., 178(7):721-8, 2008.

McEvoy, C. T. \& Spindel, E. R. Pulmonary effects of maternal smoking on the fetus and child: effects on lung development, respiratory morbidities, and life long lung health. Paediatr. Respir. Rev., 21:27-33, 2017.

McEvoy, C. T.; Schilling, D.; Clay, N.; Jackson, K.; Go, M. D.; Spitale, P.; Bunten, C.; Leiva, M.; Gonzales, D.; Hollister-Smith, J.; et al. Vitamin $\mathrm{C}$ supplementation for pregnant smoking women and pulmonary function in their newborn infants: a randomized clinical trial. JAMA, 311(20):2074-82, 2014.

Mühlfeld, C. \& Ochs, M. Quantitative microscopy of the lung: a problembased approach. Part 2: stereological parameters and study designs in various diseases of the respiratory tract. Am. J. Physiol. Lung Cell Mol. Phisiol., 305(3):205-21, 2013.

National Research Council (US) Committee for the Update of the Guide for the Care and Use of Laboratory Animals. Guide for the Care and Use of Laboratory Animals. $8^{\text {th }}$ edition. Washington (DC), National Academies Press (US), 2011. Available from: https:// www.ncbi.nlm.nih.gov/books/NBK54050

Nolen, R. S. AVMA board approves Panel on Euthanasia report: updated guidelines cover more species and methods. J. Am. Vet. Med. Assoc., 239(10):1269, 2011.

Raja, S.; Chandrasekaran, S. R.; Lin, L.; Xia, X.; Hopke, P. K. \& Valsaraj, K. T. Analysis of beta attenuation monitor filter rolls for particulate matter speciation. Aerosol Air. Qual. Res., 17(1):14-23, 2017.

Reyes, R.; Schueftan, A.; Ruiz, C. \& González, A. D. Controlling air pollution in a context of high energy poverty levels in southern Chile: Clean air but colder houses? Energy Policy, 124:301-11, 2019.

Sanhueza, P. A.; Torreblanca, M. A.; Diaz-Robles, L. A.; Schiappacasse, L. N.; Silva, M. P. \& Astete, T. D. Particulate air pollution and health effects for cardiovascular and respiratory causes in Temuco, Chile: a wood-smoke-polluted urban area. J. Air Waste Manag. Assoc., 59(12):1481-8, 2009.

Sanhueza, P.; Vargas, C. \& Mellado, P. Impact of air pollution by fine particulate matter (PM10) on daily mortality in Temuco, Chile. Rev. Med. Chil., 134(6):754-61, 2006.

Schiappacasse, P. N.; Díaz-Robles, L. A.; Cereceda-Balic, F. \& Silva, S. P. Health impacts in South-central Chile due to misuse of wood-burning stoves. Electron. J. Energy Environ., 1(3):65-71, 2013.

Schueftan, A. \& González, A. D. Reduction of firewood consumption by households in south-central Chile associated with energy efficiency programs. Energy Policy, 63:823-32, 2013.

Tang, W.; Du, L.; Sun, W.; Yu, Z.; He, F.; Chen, J.; Li, X.; Li, X.; Yu, L. \&
Chen, D. Maternal exposure to fine particulate air pollution induces epithelial-to-mesenchymal transition resulting in postnatal pulmonary dysfunction mediated by transforming growth factor-b/Smad3 signaling. Toxicol. Lett., 267:11-20, 2017.

Tschanz, S. A.; Burri, P. H. \& Weibel, E. R. A simple tool for stereological assessment of digital images: the STEPanizer. J. Microsc., 243(1):4759, 2011.

Vasquez, M. M.; Zhou, M.; Hu, C.; Martinez, F. D. \& Guerra, S. Low lung function in young adult life is associated with early mortality. Am. J. Respir. Crit. Care Med., 195(10):1399-401, 2017.

Veras, M.; Damaceno-Rodrigues, N.; Caldini, E. G.; Maciel Ribeiro, A. A.; Mayhew, T. M.; Saldiva, P. H. \& Dolhnikoff, M. Particulate urban air pollution affects the functional morphology of mouse placenta. Biol. Reprod., 79(3):578-84, 2008.

Villalobos, A. M.; Barraza, F.; Jorquera, H. \& Schauer, J. J. Wood burning pollution in southern Chile: PM2.5 source apportionment using CMB and molecular markers. Environ. Pollut., 225:514-23, 2017.

World Health Organization (WHO). Ambient (Outdoor) Air Pollution DataBase, by Country And City. Ambient (Outdoor) Air Pollution in Cities Database. Geneva, World Health Organization, 2018b.

World Health Organization (WHO). Global Urban Ambient Air Pollution Database, update 2016. Geneva, World Health Organization, 2018a. Available from: http://www.who.int/airpollution/data/cities-2016/en/

World Health Organization (WHO). WHO's Urban Ambient Air Pollution data base-Update 2016 version 0.2. Geneva, World Health Organization, 2016. Available from: https://www.who.int/phe/ health_topics/outdoorair/databases/AAP_database_summary_res

\author{
Corresponding author: \\ Paulo Salinas \\ Laboratory of Animal \& Experimental Morphology \\ Institute of Biology \\ Faculty of Science*s \\ Pontificia Universidad Católica de Valparaíso \\ Av. Universidad \# 330 \\ Curauma 3100000 \\ Valparaíso \\ CHILE
}

Email: paulo.salinas@pucv.cl

ORCID: https://orcid.org/0000-0003-2273-

Received: 12-04-2020

Accepted: 13-05-2020 